\title{
MANAGEMENT INFORMATION SYSTEM (MIS) AS A PART OF THE COMPLEX DECISION SUPPORT SYSTEM IN BUSINESS
}

Анотація. У статті визначено та проаналізовано головні концепти систем управління інформацією. Обгрунтовані особливості подання коректної інформації, а також ї̈ повнота, своєчасність, актуальність, рівень агрегації, надійність, точність, застосовність та економічна ефективність. Визначено місце системи управління інформацією в процесі прийняття рішення та ї̈ важлливість. Описано чотири існуючих системи управління інформацією, а саме: система управління базами даних, система інформаційного передбачення, інформаційна система розроблення рішення, інформаційна система прийняття рішення. Розтлумачено базові концепти застосування комп'ютера в роботі. Проаналізовано переваги та недоліки централізованої системи децентралізованих версій.

Ключові слова: система управління інформацією, система управління базою даних, система інформаційного передбачення, інформаційна система розроблення рішення, інформаційна система прийняття рішення.

Summary. In this article we have notified and analyzed the main concepts of a management information system. The features of correct information, as also its exhaustiveness, timeliness, relevance, aggregation level, reliability, accuracy, usability, and cost-effectiveness have been described. The place of management information systems in the process of decision making and the value of information have been defined. We have described four types of MIS, they are: databank information system, predictive information system, decision-making information system, and decisiontaking information system. Basic computer concepts have been explained. The advantages and disadvantages of centralized versus decentralized systems have been examined.

Key words: management information system, databank information system, predictive information system, decision-making information system, decision-taking information system.

$$
\text { DOI : 10.33783/1977-4167-2020-47-1-90-94 }
$$

(C) Д. І. Соловйов, М. Ю. Статьєва, Т. І. Трушнікова, 2020

\section{Бібліографія ДСТУ 8302:2015:}

Solovyov, D. I., Statyeva, M. Yu., Trushnikova, T. .I. Management information system (MIS) as a part of the complex decision support system in business. Вісник Бердянського університету менеджменту і бізнесу. 2020. № 1 (47). С. 90-94.

References (APA):

Solovyov, D. I., Statyeva, M. Yu., Trushnikova, T. I. (2020). Management information system (MIS) as a part of the complex decision support system in business. Visnyk Berdianskoho universytetu menedzhmentu i biznesu, 1 (47), 90-94 (in Ukr.). 
Articulation of the problem. Information is an important agent in the managing business and business organizations. Permanently accessible actual information is a condition for doing well the managerial activities such as leading, organizing, planning, and control. The information business system created as a human nervous system, it has numerous links that connects all the structure's components together. It also provides the better functioning and surviving in a competitive marketing environment. One way or another, modern business organizations build on information.

A computer-based system was created to support and ensure the management, as well their related operations, and multiple decision functions of a business organizations. In business management information systems organizations provide information support especially for decision makers. Management information systems ensure the operation of the management information systems, design processing systems, and keep decision support systems and strategic information systems in their work condition.

The worked up information must be understandable to a user and contains all data the business need. The business information system is the most important component that operates to achieve a needed purpose. Sometimes a management information system is difficult and time-consuming to gather, transmit process and store data contained onto all business resources and programs. The decision makers within the organization need up to date management information to use, so it should be designed and launched as a system that makes possible to use and produce the business conversion A management information system, therefore, produces information that supports the management functions of an organization.

Analysis of the recent researches and publications. Management information systems are well studied and analyzed by numerous scientists and researchers on the most important directions such as databank information system, predictive information system, decision-making information system, and decision-taking information system. However new-comings from the business societies let us precise and develop the stable concepts that grounded the task areas. We're appreciate to Ahituv, Neumann, \& Riley for the description of the decision-making process in a way that information is obscure and the outcomes are scaled by multiple and incomparable dimensions so it can attempt to perform a multi attribute analysis or derive an overall subjective value [1]. To Awad, E. M., \& Gotterer, M. H., Banerjee, U. K., \& Sachdeva, R. K who describes the process of decision making as comprising four steps: intelligence, design, choice, and review and enter the meaning of intelligence stage, it can encompass collection, make classification, processing, and presentation of data relating to the organization and its environment $[2 ; 3]$. This is necessary to identify situations calling for decision because there are various types of manage- ment information systems. To Davis G. B., and Olson M. H., Imboden N., Keen, P. G., \& Morton M. S., they described four categories of management information systems: (1) databank information system, (2) predictive information system, (3) decision-making information system, and (4) decision-taking information system $[4 ; 5 ; 6]$. The classification is based on the level of support that the information system provides in the process of decision making. To Lucas, H. C., Jr. who comprehensively presents these four types of systems: Databank Information System, Predictive Information System, Decision-Making Information System, Decision-Taking Information System [7]. To Martin, J. they designed a decision support system (DSS), this set of programs is the model based on Non redundancy and means that each individual piece of data exists only once in the database [8]. Mason, R. D., \& Swanson, B. E., they defined that an appropriate structure means that the data are stored in such a way as to minimize the cost of expected processing and storage. All these much respected person made a solid base for further development of the management information systems and their successful appliances [9].

The purpose is to summarize all the information up to date and to analyze the applying of management information systems in the process of decision making and decision taking activities.

Presentation of the main research material. Information is data that have been put into a meaningful and useful context and communicated to a recipient who uses it to make decisions. Information involves the communication and reception of intelligence or knowledge. It appraises and notifies surprises and stimulates, reduces uncertainty, reveals additional alternatives or helps eliminate irrelevant or poor ones, and influences individuals and stimulates them to action. An element of data may constitute information in a specific context; for example, when you want to contact your friend, his or her telephone number is a piece of information; otherwise, it is just one element of data in the telephone directory. Computers are able to process the most functions much easy; the big amount of data can be processed quickly through computers through the conversion to the informed data. Some data enter into the system and are transformed into the system's output, that is, information to help managers in their decision making.

The Information in general has some specific characteristics we can to describe and specify.

The characteristics of good information are relevance, timeliness, accuracy, cost-effectiveness, reliability, usability, exhaustiveness, and aggregation level.

Information is relevant if it goes to improve good decision making. It might also be relevant if it improves a previous decision. If it does not have anything to do with your questions, it is unsuitable.

Timeliness refers to the acceptance of the information presented to the users. Prevalence of data or 
information is the time gap between the occurrences of an event in the field until its presentation to the user (decision maker). When this amount of time is very short, we describe the information system as a realtime system.

Accuracy is measured by studying the data to upto-date events. The importance of accurate data differs with the kind of decisions that we need to make. Payroll presented information must be always exact. Approximations will not relevant. For example, a general estimation of how much time was devoted to a particular staff activity should be considered as all that they need for.

The value of Information is the next important question to resolve.

Information has a great impact on decision making, and consequently its value is tied to the result of the decisions we make and apply. Information itself doesn't have a universal value. Its value is related to those specialists who use it, when it is used, and to the situation when used. In such a context, information is similar to other obstacles.

Economists distinguish value from cost or price of a commodity incurred to produce or procure the commodity. Obviously, the value of a product must be higher than its cost or price for it to be cost-effective [1: 15].

The concept of normative value of information has been developed by economists and statisticians and is derived from decision theory [2:48]. The basic argument of the theory is that we always have some preliminary knowledge about the case of events that are applicable to our decisions. Additional information might modify our view of the occurrence possibilities and accordingly change our decision and the expected payoff as a result of the decision. The value of additional information is, therefore, the difference in expected pay off received by reduced uncertainty about the future event [2: 57].

Information supports decisions, decisions trigger actions, and actions affect the achievements or performance of the organization. «If we can measure the differences in performance, we can trace the impact of information, provided that the measurements are carefully performed, the relationships among variables are well defined, and possible effects of irrelevant factors are isolated. The measured difference in performance due to informational factors is called the realistic value or revealed value of information [3: 89]».

For most information systems, especially those that support middle and top levels of management, the resulting decisions often relate to events that are not strictly defined and involve probabilities that cannot be quantified. The decision-making process often is obscure and the outcomes are scaled by multiple and incomparable dimensions. In such cases, we may either attempt to perform a multi attribute analysis or derive an overall subjective value. The subjective value reflects people's comprehensive impression of information and the amount they are willing to pay for specific information [3: 125].

Information as an Aid to Decision Making. By Simon the process of decision making as comprising four steps: intelligence, design, choice, and review. The intelligence stage encompasses collection, classification, processing, and presentation of data relating to the organization and its environment. This is necessary to identify situations calling for decision. During the decision stage, the decision maker outlines alternative solutions, each of which involves a set of actions to be taken. The data gathered during the intelligence stage are now used by statistical and other models to forecast possible outcomes for each alternative. Each alternative can also be examined for technological, behavioral, and economic feasibility. In the choice stage, the decision maker must select one of the alternatives that will best contribute to the goals of the organization [4:234].

How better to classify the Management Information Systems. There are various types of management information systems. The researches Mason and Swanson describe four categories of management information systems: databank information system, predictive information system, decision-making information system, and decision-taking information system. The classification is based on the level of support that the information system provides in the process of decision making.

Databank Information System is about to observe, classify, and store any item of data which might be potentially useful to the decision maker. A second example of data that might be recorded in a database (this time involving data internal to the organization) is as follows:

- number of extension staff by category and assigned to a particular business;

- number of work hours devoted by staff to selected concerns for a particular business;

- total extension salary costs and other expenses by a particular business;

- number of demonstrations conducted for selected farm technologies a particular business;

- number of on-farm trials conducted for selected farm technologies a particular business.

Each of these databases can be summarized and converted to single tabular presentations of information of interest to management. When information from two or more time periods is compared, trends can be observed.

Predictive Information System. This system moves beyond pure data collection and the determination of trends over time. Predictive information systems provide for the drawing of inferences and predictions that are relevant to decision making. If data from the above examples were to be used in this way, it is possible to obtain information useful for making predictions or 
for drawing inferences. For example, tables containing the following information for a given village, region, or area might be produced:

- the ratio between the number of farms and the various categories of extension staff members;

- the ratio between the amount of farmland and the various categories of extension staff members;

- amount of extension financial operating resources allocated per year to selected farmer problems or concerns;

- amount of extension financial resources, both salary and operating expenses, allocated per year to selected extension approaches to solving different farmer problems or concerns.

Information obtained from these kinds of analyses is normally summarized in a two-way tabular format. And likewise, the information often is compared over time. Managers can then use such information to make predictions, for example to forecast costs of particular undertakings for budgeting purposes or as a basis for predicting results if a given change is made, such as change in the number of demonstrations with a given change in staffing.

Decision-Making Information System goes one step further in the process of decision making and incorporates the value system of the organization or its criteria for choosing among alternatives. An extension organization's values are many and varied. They include concerns for resolving business problems, increasing and providing for stability of business incomes, and improving the quality of business life. But they also including and providing for stability of business incomes, and improving the quality of business life. But they also include an intent to provide well for staff members (training, adequate salaries, etc.) and to aid in the process of bringing about economic development.

Information regarding these various attributes helps managers to make more enlightened decisions.

Decision-Taking Information System is a decision system in which the information system and the decision maker are one and the same. Management is so confident in the assumptions incorporated in the system that it basically relegates its power to initiate action to the system itself. Airplanes carry automatic pilot systems, which are an example of a decisiontaking system. Once activated, the system itself keeps the plane on course and at the proper speed and altitude (according to parameters determined by the pilot). Another example of decision-taking information systems is found in modem factory production. In automobile production, continuous inventories of parts are maintained by computer as cars move down an assembly line. Orders are placed automatically by the computer when additional parts are needed. This is done without the intervention of a manager.

As suggested above, at every phase of the management process, managers need information in order to make effective decisions. This we call management information. It does not include purely functional information or technical information, such as packages of practices for rice or wheat cultivation. Management information is the information required by managers as they make their decisions, such as the number of extension personnel employed by category, their training requirements, career development plans, job descriptions, budgets, forecasts, benchmark surveys, reports on socioeconomic conditions of people served, and existing facilities The main purpose of management information systems is to provide management information to decision makers at various levels in the organization.

Flexibility means the ability to retrieve information from a system in whatever form it may be needed by decision makers. Therefore, data need to be collected in some detail so that they can be rearranged or summarized according to the needs of managers. But system design should not be too complex because it must first serve the needs of the lowest levels of management that are likely to be instrumental in collecting important components of the original data. In addition, the system also must serve the needs of the district, regional, state or provincial, and national levels. Therefore, considerable care must be taken in assessing what types of information are required by management at the different levels. At the same time, effort must be made to ensure that the information collected meets acceptable standards of accuracy, timeliness, and coverage for each level.

Organization of a database. Data are usually generated at the field level through transaction-processing systems, but once the data are captured, any echelon along the organizational hierarchy may use them, provided that information requirements have been well defined, appropriate programmes have been implemented, and a means has been arranged for the sharing of the data. This would imply that the same data can be used by different sets of programs; hence we distinguish between the database (a set of data) and the applications (a set of programs). In a decision support system (DSS), this set of programs is the model base [5: 97].

The term database may refer to any collection of data that might serve an organizational unit. A database on a given subject is a collection of data on that subject that observes three criteria: comprehensiveness (completeness) and appropriate structure. Comprehensiveness means that all the data about the subject are actually present in the database. Non redundancy means that each individual piece of data exists only once in the database. Appropriate structure means that the data are stored in such a way as to minimize the cost of expected processing and storage.]The idea of a large corporate database that can be flexibly shared by several applications or model bases has been realized by means of software packages specially devised to perform such tasks. 
These packages, called database management systems (DBMSs), are available in the market under different trade names such as ORACLE, SYBASE, INGRES, FOXBASE, and dBASE [6:147; 7,8,9].

Networking and interactive processing. The two principal blocks that facilitate development and use of MIS are DBMS and telecommunications. The former makes data integration possible, while the latter brings information closer to the end users, who constitute nodes in a telecommunication network. The notion of telecommunications implies that some geographical distance exists between the computer site and the users' locations and that data are electronically transmitted between them. Remote applications may be executed between two floors in the same building, two offices in the same city, two offices on the same continent, or two places on opposite sides of the globe [7:38].

Conclusions we made. The need for organizing databases and their integration and the need for programs for decision analysis to evolve a decision support system have been explained. An assessment of hardware, software, and networking requirements for a typical computer-based MIS for a national agricultural extension system has been illustrated. Data refers to raw, unevaluated facts, figures, symbols, objects, events, etc. Data may be a collection of facts lying in storage, like a telephone directory or census records.

First is the characteristics of good information are relevance, timeliness, accuracy, cost-effectiveness, reliability, usability, exhaustiveness, and aggregation level.

Second is the information is relevant if it goes to improve good decision making. It might also be relevant if it improves a previous decision.

Third is timeliness refers to the acceptance of the information presented to the users. Prevalence of data or information is the time gap between the occurrences of an event in the field until its presentation to the user (decision maker). When this amount of time is very short, we describe the information system as a real-time system.

Fourth is accuracy is measured by studying the data to up-to-date events. The importance of accurate data differs with the kind of decisions that we need to make. Payroll presented information must be always exact.

\section{Література}

1. Ahituv, N., Neumann, S., \& Riley, H. N. (2004). Principles of information systems for manage- ment (4th ed.). Dubuque, IA: Wm. C. Brown Communications.

2. Awad, E. M., \& Gotterer, M. H. (2002).Database management. Danvers, MA: Boyd \& Fraser.

3. Banerjee, U. K., \& Sachdeva, R. K. (2005). Management information system: A new frame work. New Delhi: Vikas Publishing House.

4. Davis, G. B., \& Olson, M. H. (2005). Management information systems: Conceptual foundations, structure, and development. New York: McGraw-Hill.

5. Imboden, N. (2002). Managing information for rural development projects. Paris: Organization for Economic Co-operation and Development.

6. Keen, P. G. W., \& Morton, M. S. (2018). Decision support systems. Reading, MA: Addison-Wesley.

7. Lucas, H. C., Jr. (2010). Information systems concepts for management. New York: McGraw-Hill.

8. Martin, J. (2010). Telecommunications and the computer (3rd ed.). Englewood Cliffs, NJ: PrenticeHall.

9. Mason, R. D., \& Swanson, B. E. (2011). Measurements for management decision. Reading, MA: Addison-Wesley.

\section{References}

1. Ahituv, N., Neumann, S., \& Riley, H. N. (2004). Principles of information systems for management (4th ed.). Dubuque, IA: Wm. C. Brown Communications.

2. Awad, E. M., \& Gotterer, M. H. (2002).Database management. Danvers, MA: Boyd \& Fraser.

3. Banerjee, U. K., \& Sachdeva, R. K. (2005). Management information system: A new frame work. New Delhi: Vikas Publishing House.

4. Davis, G. B., \& Olson, M. H. (2005). Management information systems: Conceptual foundations, structure, and development. New York: McGraw-Hill.

5. Imboden, N. (2002). Managing information for rural development projects. Paris: Organization for Economic Co-operation and Development.

6. Keen, P. G. W., \& Morton, M. S. (2018). Decision support systems. Reading, MA: Addison-Wesley.

7. Lucas, H. C., Jr. (2010). Information systems concepts for management. New York: McGraw-Hill.

8. Martin, J. (2010). Telecommunications and the computer (3rd ed.). Englewood Cliffs, NJ: Prentice-Hall.

9. Mason, R. D., \& Swanson, B. E. (2011). Measurements for management decision. Reading, MA: Addison-Wesley. 